\title{
The Symbiosis of Offline and Digital Retail: Ukrainian Context
}

\begin{abstract}
Alona O. Natorina ${ }^{i}$
It is substantiated and scientifically proved that retail is one of the components of the Ukrainian economy in the context of ensuring its sustainable development. The arguments about the determination of the symbiosis of offline and digital retail as one of the alternatives for successful operations in a modern environment with permanent market changes are summarized considering the trend of digitalization. The purposes of the paper are to investigate the landscape and features of digital and offline businesses of retailers, and to justify recommendations for retailers with a trade network for their persistent digital business development in the context of Ukrainian realities. The object of the study is the largest Ukrainian retailers in the food retail segment, which carrying out simultaneous online and offline trade. As part of the study, the analysis of the volumes of online trade in the general structure of Ukraine's trade turnover during 2014-2019 years was carried out. The trends of the Ukrainian online trading market in Europe are identified. The comparative analysis of the spending volume of online retail in Ukraine, Eastern Europe and the world in 2014-2020 years was conducted. Prospects for doing digital business for retailers in Ukraine are substantiated. The features of the online buyers' activities in the online space are diagnosed. The digital activity of consumers by the types of gadgets and devices in Ukraine and the world is determined. Trends in Ukrainian online retail is interpreted. The development of the digital business of Ukrainian food retailers is analysed. Based on the results of diagnostics of the Ukrainian retailers' activity in the food retail segment and taking into account current market trends, perspective directions of persistent progressive development of their digital business are determined. Approbation of the recommendations that are provided in the article, is confirmed the feasibility of their usage by online retailers in Ukraine to maximize the satisfaction of heterogeneous requests, needs and preferences of online buyers, as well as the rapid expansion of new market segments.
\end{abstract}

Keywords: digitalization, digital business, digital transformation, offline business, retail.

УДК 658.6:004.738.5

JEL Codes: L81, M1

Introduction. Retail is one of the components of the Ukrainian economy in the context of ensuring its sustainable development. Maximum satisfaction of the demands, needs and preferences of buyers is one of the driving forces for providing sufficient level of traditional retailers' (offline business) competitiveness for the market functioning. The trend of digitalization contributed, among other things, to reactive changes in the widespread buyer's behaviour and preferences dictated three alternative options for the possible success of retailers in the modern environment: (a) do business (trade) only online; (b) trade offline and partly use online marketing tools; (c) combine offline and online trading. The last third option requires the development of digital business by retailers, that is, retailers should conduct online trading with offline. This underlines the relevance and importance of exploring rational ways of realization both - digital and offline businesses.

Problem statement. Digital technologies are transforming operations, products and services in organizations large and small. The digital transformation of organizations is extolled as a solution to organizational challenges related to both efficiency and effectiveness [5].

${ }^{i}$ Alona O. Natorina, C.Sc. (Economics), Acting Head, Department of International Economics, Accounting and Finance, Academician Yuriy Bugay International Scientific and Technical University.

(C) A. O. Natorina, 2019.

https://doi.org/10.21272/mer.2019.85.04 


\section{А. О. Наторіна.}

Симбіоз офлайн та діджитал ритейлу: украӥнський контекст

Digitalization denotes an on-going transformation of great importance for the retail sector [6]. The pace of retail evolution has increased dramatically, with the spread of the Internet and as consumers have become more empowered by mobile phones and smart devices [3].

Digital transformation has a strong impact on the retail industry. Activities that were once retail sector are moving to online stores, and specialized third parties are taking over physical distribution and payment. In our digital age, need occurrence, shopping and consumption are moving much closer in time and space and are being naturally integrated into our daily routine [11].

The above demonstrates the importance of understanding the correct convergence of traditional offline trading with digital business (online trading) in retail. The question of adapting the activities of existing traditional retailers in a digital transformation period is also significant. Despite the presence of a sufficiently large number of publications about the digital business, the specifics and features of the digital business realization in terms when retailers have successful trade network are not studied in detail.

The purposes of the research are to investigate the landscape and features of digital and offline businesses of retailers, and to justify recommendations for retailers with a trade network for their persistent digital business development in the context of Ukrainian realities.

Results of the research. Monitoring features of retailer's business in Ukraine plays an important and priority role in the economic situation, because the increase in online retailers' sales affects the turnover of Ukraine (Figure 1) and contributes the sustainable development of the economy.

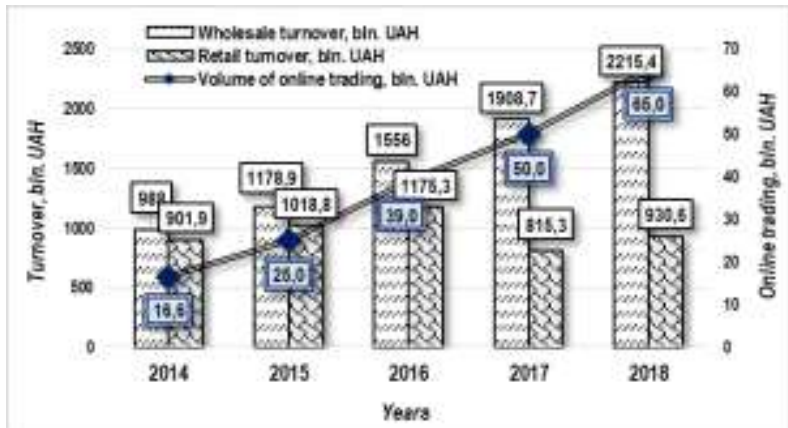

Notes. Data exclude the temporarily occupied territory of the Autonomous Republic of Crimea, the city of Sevastopol and a part of temporarily occupied territories in the Donetsk and Luhansk regions.

Figure 1. The structure of Ukrainian goods turnover in 2014-2018 years [developed by the author according $[2,14]]$

According to the State Statistics Service of Ukraine, the turnover of wholesale enterprises increased 2.2 times during 2014-2018 years. However, if we consider the dynamics of the turnover of retail enterprises (despite their growth in 2018 year compared to 2014 year) in 2017-2018 years it was significantly less than in 2015-2016 years. The changes have affected the overall structure of the whole enterprises' turnover in 2017 year (2 724.0 bln UAH), which was $15.5 \%$ less turnover in 2018 year. Therefore, in the whole, it was a positive trend regarding the increase in Ukraine turnover. In the structure of the turnover, the volume of wholesale enterprises increased annually for five years, and the positive changes in the turnover of retail enterprises were episodic. 
An important aspect of the study is focusing on the volume of online trade in Ukraine, which was rapidly increased over 2014-2018 years and in 2018 year amounted to 65.0 bln UAH. That was almost 4 times more than in 2014 year. In 2019 year, according to EVO Company, online trading volumes will be 1.3 times more than in 2018 year. So, the growth rate in 2019 year will be a bit slowly than in 2018 year, but also significant for country's economy.

The calculations show a steady increase in the percentage of online trade in the structure of the turnover of wholesale enterprises during 2014-2018 years. Moreover, in the 2016-2017 years the increase in online trade in the structure of the turnover of enterprises in Ukraine was higher than in the other studied periods. This indicates the popularization and active development of online trade in Ukraine, as well as a marked increase in online purchases.

The Ukrainian Retail Association emphasizes that online sales, although they represent a small share of total retail turnover - no more than $3 \%$, have a rapid annual increase. Moreover, according to EVO. Business, in 2018 year the online trading market was the second fastest growing in Europe. According to forecasts by the analysts of the Nakono, by 2020 it will be a positive dynamic in online retail - a steady increase in average monthly spending per buyers in online retail in Ukraine, Eastern Europe and the world (Figure 2).

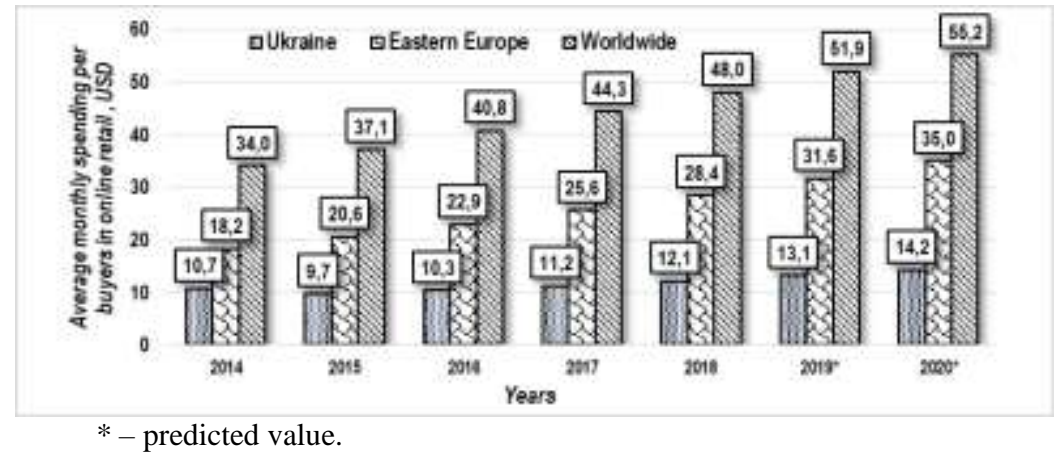

Figure 2. Average monthly spending per buyers in online retail in 2014-2020 years [developed by the author according [7]]

Figures 2 shows the increase of the average monthly spending of Ukrainian online buyers during 2016-2018 years. The predicted value of these costs in 2020 year will be $8.4 \%$ more than in 2019 year. As for the average monthly spending of buyers in Eastern Europe and the world in online retail. It will be a tendency to increase costs in 2020 year due to the use in practice of various online channels. In particular, the average monthly spending per buyers in online retail in Eastern Europe in 2020 year will be almost 2 times more than in 2014 year. It is predicted that similar spending in the world in 2020 year will be $62.4 \%$ higher than in 2014 year. In order to analyze the dynamics of total online retail expenditure across all channels in 2014-2020 years in Ukraine, Eastern Europe and the world, the author developed the Table 1.

According to the Table 1, since 2016 year the total online retail expenditure across all channels in Ukraine tend to increase. This is due to (a) the improvement of the economic situation in the country and (b) the adaptation of online retailers to changes in the competitive environment and (c) the formation of appropriate policies to satisfy online buyers. Since 2014 year, in Eastern Europe and the world, there was a steady growth in the volume of total 


\section{А. О. Наторіна.}

Симбіоз офлайн та діджитал ритейлу: украӥнський контекст

online retail expenditure across all channels, which indicated an active attraction of buyers to make purchases in online stores. In Eastern Europe in 2020 year compared to 2014 year, the percentage of the total online retail expenditure increase will be $107.7 \%$, and $107.6 \%$ - in the world.

Table 1

The total online retail expenditure across all channels, in 2014-2020 years, mln USD [developed by the author according [7]]

\begin{tabular}{|c|c|c|c|}
\hline Year & Ukraine & Eastern Europe & Worldwide \\
\hline 2014 & 2474.560 & 42698.262 & 1279970.430 \\
\hline 2015 & 2300.000 & 49330.373 & 1495213.632 \\
\hline 2016 & 2470.000 & 55765.325 & 1716910.995 \\
\hline 2017 & 2692.300 & 63033.554 & 1937534.905 \\
\hline 2018 & 2934.607 & 70965.732 & 2170654.960 \\
\hline $2019^{*}$ & 3198.722 & 79524.429 & 2424215.127 \\
\hline $2020^{*}$ & 3486.607 & 88670.890 & 2657175.705 \\
\hline
\end{tabular}

* - predicted value.

Thus, the previously mentioned emphasizes the expediency and prospects of the digital business realization by Ukrainian retailers in the future. It is important for retailers to transform their activities in a timely manner in accordance with the changing demands of online buyers, as well as to consider the actions of priority competitors. At the same time, retailers should use the relevant methodological tools that will provide the desired stable operation and minimize the negative impact of environment.

To increase sales retailers, monitor the interests of buyers using different gadgets and devices. It increases the business opportunities of retailers in the Internet. Purchases online has a number of advantages for the buyers, as opposed to traditional offline. One of these advantages is the extensive coverage of the Internet, due to which buyers can buy goods in a convenient place and at a reasonable time. In addition, retailers can quickly deliver the goods. According to analytical materials of Kantar TNS, in 2018 year the number of Internet users in Ukraine aged 12 to 70 years increased by $7 \%$ compared with 2017 year and amounted to $70 \%$. The behavior of users in the Internet is not a permanent and cannot be accurately predicted. Therefore, retailers monitor the main changes in the requests of the potential online buyers and collect anonymous information from all possible gadgets and devices. Considering the fact that providing online buyers with comprehensive information about retailer is possible by using different digital channels, it is important for retailers to know the most common and popular gadgets and devices among buyers.

The rapid growth of buyer's gadgets and devices usage highlights the importance of adapting retailers' activity in online. Since 2016 year, the digital activity of Ukrainian Internet audience has transformed. According to Kantar TNS experts, in 2018 year, the mobilecentered Ukrainian Internet audience increased. Mobile Internet devices in 2018 year were used by $16.7 \mathrm{mln}$. Ukrainians aged $12-70$, that are $15.5 \%$ more than in 2017 year. In general, in Ukraine, the share of users entering the Internet through a desktop is gradually decreasing. In 2018 year, their share was $82 \%$, which is $7 \%$ less than in 2017 year. This trend is due to a significant increase of smartphones on the Ukrainian market. A similar situation was in the previous few years because of the proliferation of $3 \mathrm{G}$ and $4 \mathrm{G}$ networks. 
Alona O. Natorina.

The Symbiosis of Offline and Digital Retail: Ukrainian Context

In 2018 year, the average time spent by the Ukrainian Internet user on the Internet is 5.5 hours per day, which is 0.6 hours longer than the average resident of Europe and 0.5 hours more Internet users in the world. About $80 \%$ of smartphone usage time was spent on mobile applications for finding product information (39\%), video views (36\%), and online purchases (25\%). The largest percentage among the Ukrainian Internet audience that used mobile applications for online purchases was in the age group of 26-35 years (35\%). Also, Internet users aged 16-25 and 36-45 actively engaged in online shopping through mobile applications, namely, their percentages were $34 \%$ and $32 \%$. Therefore, retailers in Ukraine should consider Internet users of the age group of $16-45$ as a promising and top priority when will develop their digital business.

Successful communication retailers with online buyers through mobile applications and personalized online store services is possible with the fast Internet speed. According to Cable and M-Lab research, in 2019 year Ukraine ranked 81st among 207 countries at the speed of the Internet, losing 23 positions compared with 2018 year, where it ranked 58th. The average download Internet speed in Ukraine in 2019 year amounted to 7.72 megabits per second, that is, downloading a file of 5 gigabytes takes about 1.5 hours. This allows us to conclude that it is necessary for retailers to take into account Internet speed to ensure the stable operation of the online store and relevant mobile applications. It is also advisable for retailers to take into account the Internet speed and optimize the site in order to reduce the download time of relevant web pages and / or information messages in applications for easy usage by buyers.

Despite the transition of a certain part of the Internet audience in Ukraine to the use of mobile devices, among the online buyers in 2018 year, the prevailing part of them (62\%) made purchases of goods in the Internet using desktops, $34 \%$ (about a third) used smartphones, and only $4 \%$ - tablets. The average check of online buyer in Ukraine was 74 USD (Figure 3).

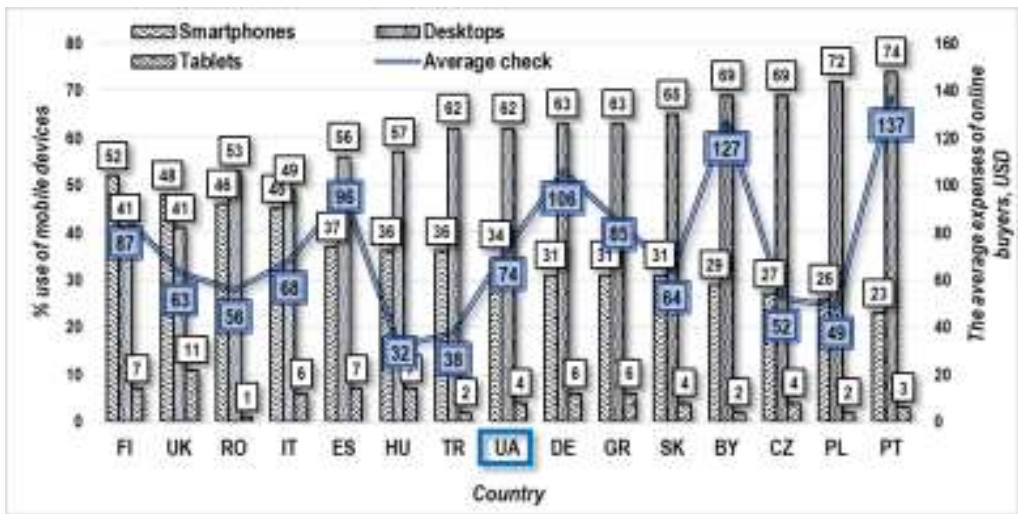

Notes. BY - Belarus, CZ - Czech Republic, DE - Germany, ES - Spain, FI - Finland, GR - Greece, HU - Hungary, IT - Italy, PL - Poland, PT - Portugal, RO - Romania, SK - Slovak Republic, TR - Turkey, UA - Ukraine, UK - United Kingdom.

Figure 3. Use of devices by online buyers in Europe and their average costs in 2018 year [developed by the author according [10]]

According to Figure 3, $31 \%$ of online buyers from Germany, Greece and the Slovak Republic in 2018 year made an online order through a smartphone, as well as Ukrainian online buyers. The percentage of online buyers with smartphones in Hungary and Turkey is slightly 


\section{А. О. Наторіна.}

Симбіоз офлайн та діджитал ритейлу: украӥнський контекст

higher $(36 \%)$. Thus, in these countries about one-third of online buyers are more comfortable to buy goods by using a smartphone. $62 \%$ of online buyers in Turkey made purchases using desktops. It demonstrates a situation identical to Ukraine. As for the size of the average check, the Italians spent in 2018 year on online purchases 6 USD less than Ukrainian, and the average expenses of one online buyer from Greece were 11 USD more than Ukrainian online buyers. The difference is significant and can be explained by the different purchasing power of online buyers, as well as the structure of the Internet audience.

It is important to note the fact that the demand for goods in the Internet among Ukrainian buyers is gradually shifted towards daily goods. The research results of a global company Nielsen [9] show that in the next few years the Europe market will be characterized by an increase in online sales of FMCG demand. Therefore, in this context, an important issue is the adaptation to the external environment, where the quality of satisfaction of buyers' preferences plays a major role.

To conduct an analytical study, from Ukrainian retailers with the largest offline trade network in the segment of food-retail the author selected those who carry out the digital business (online trade) through the online store. Currently, Ukrainian online buyers make orders of FMCG in online shops. Only a small part of them makes purchases through the marketplaces. According to Similarweb, in 6 months of 2019 year among food-retailers in Ukraine the largest number of visits had the online store METRO (Table 2).

Traffic overview of the food-retailers' online stores in 2019 year

Table 2 [developed by the author according [12]]

\begin{tabular}{|l|c|c|c|c|c|c|}
\hline \multirow{2}{*}{ Online store } & \multicolumn{7}{|c|}{ Total visits, mln } \\
\cline { 2 - 7 } & January & February & March & April & May & June \\
\hline $\begin{array}{l}\text { AUCHAN } \\
\text { https://shop.auchan.ua }\end{array}$ & 0.25 & 0.23 & 0.31 & 0.30 & 0.31 & 0.55 \\
\hline $\begin{array}{l}\text { METRO } \\
\text { https://www.metro.ua/e-shop }\end{array}$ & 0.46 & 0.43 & 0.54 & 0.61 & 0.55 & 1.50 \\
\hline $\begin{array}{l}\text { NOVUS } \\
\text { https://novus.zakaz.ua }\end{array}$ & 0.22 & 0.19 & 0.22 & 0.25 & 0.26 & 0.19 \\
\hline $\begin{array}{l}\text { Tavria V } \\
\text { http://www.tavriav.ua }\end{array}$ & 0.19 & 0.27 & 0.31 & 0.19 & 0.22 & 0.18 \\
\hline $\begin{array}{l}\text { Fozzy } \\
\text { http://fozzyshop.com.ua }\end{array}$ & 0.20 & 0.24 & 0.23 & 0.23 & 0.21 & 0.24 \\
\hline
\end{tabular}

According to the Table 2, the highest visit rate for the month in 2019 year was observed in the METRO online store. It should be noted that the dynamics of visits AUCHAN online store of had been steadily increased since the beginning of 2019 year and amounted to 0.55 million in June 2019 year, which was equal to the number of visits of the METRO online store in May. The number of visits of NOVUS, Fozzy and Tavria V online stores was in the range of 0.18 to 0.31 million people and did not have a pronounced tendency to a constant increase.

The size of the food-retail segment is very low, so it will take a long period so that the share of sales of goods in online stores of large national retailers was the same as the share of online sales of retailers in the field of home appliances and electronics. Now online buyers are just beginning to form the online trust and the realization that the purchased product online will be of the same quality as in the case of purchasing it offline. The unwillingness of buyers 
to order online FMCG is primarily due to the inability to choose them. Therefore, it is important for food-retailers to create a positive impression from their first purchase in the online store and develop certain loyalty programs to further encourage online buyers and stimulate repeated frequent orders.

The advantage of developing a digital business in the food-retail segment is the timesaving of the online buyer that he spends on choosing goods in traditional stores. Online ordering creates an opportunity for online buyers to redistribute time. Time value acts as a driving factor for online sales and contributes to the growing popularity of purchases in the Internet. However, unlike other retail segments, in Ukraine online purchase of food in the online store is more expensive than buying in a traditional supermarket. This acts as a deterrent for the development of digital business in the food-retail segment at a rapid pace. Therefore, it is advisable for online retailers to develop an appropriate system of relevant marketing activities to provide special advantageous offers for online buyers, to provide discounts and bonuses. It will allow retailers to maintain a certain format of a communicator with a target Internet audience.

Online retailers have to meet the needs of online buyers who choose the type of purchase, taking into account certain circumstances: time, prices and ease of delivery, which makes buying online more attractive. Online retailer offers are more accessible than offline. Therefore, a factor that in some way may limit the development of an online store is the lack of delivery of goods in certain regions or settlements of Ukraine. One of the key problems in the food-retail is to provide rational logistic support, which includes, in particular, supporting special temperature conditions at all successive stages of goods delivery to online buyers from the beginning of packaging to the delivery. It should be noted that there are difficulties in transporting frozen fragile goods that need to be delivered to the online buyer quickly, so the online retailer needs to develop several options for the appropriate routes taking into account traffic and road traffic in order to deliver such goods to the online buyer on time.

Conclusions. Based on the results of the diagnostics of the Ukrainian retailers' activities and taking into account current market trends, it was suggested recommendations of the progressive digital business development for retailers with offline trade network:

1. Consolidation of distributors, which provides the implementation of price controls, tougher terms of payment, the possibility of returning goods and reducing deferred payment.

2. The establishment of partnerships. Improving the efficiency of retailers, including an increase in sales, turnover of goods, stimulating demand for goods is possible thanks to (a) ensuring the optimal structure of the product portfolio; (b) systematic marketing activities that aimed at the buyers.

3. Development of the system for analyzing requests buyers. Forming a system based on information about purchases will allow retailers to determine the geography and frequency of visits, the purchases expenses, and make a standard pattern to develop effective communication with buyers.

4. Use of business intelligence marketing tools. Marketing efforts have to transform the business activities, and these business activities have to increase sales. Therefore, it is recommended to use with the marketing tools of business intelligence for correct implementation of a comprehensive assessment of marketing efforts, monitoring buyers' feedbacks and the result of retailers' activities.

5. A symbiosis of traditional and digital marketing tools. The use of multi-channel marketing with a focus on digital technology will positively affect the development of Ukrainian retailers. 


\title{
А. О. Наторіна.
}

The implementation of the suggested recommendations will strengthen the market position of Ukrainian retailers.

\section{References}

1. Cable (2019). Worldwide broadband speed league 2019. Retrieved from https://www.cable.co.uk/broadband/speed/worldwide-speed-league/.

2. EVO Company (2019). EVO. Business Publication. Retrieved from https://evo.company/ua/.

3. Grewal, D., Motyka, S. \& Levy, M. (2018). The Evolution and Future of Retailing and Retailing Education. Journal of Marketing Education, 40(1), 85-93. DOI: https://doi.org/10.1177\%2F0273475318755838.

4. Hagberg, J., Sundstrom, M. \& Egels-Zanden, N. (2016). The digitalization of retailing: an exploratory framework. International Journal of Retail \& Distribution Management, 44(7), 694-712. DOI: https://doi.org/10.1108/IJRDM-09-2015-0140.

5. Icon, C. \& Power, D. (2018). Challenges for digital transformation - towards a conceptual decision support guide for managers. Journal of Decision Systems, 27, 38-45. DOI: https://doi.org/10.1080/12460125.2018.1468697.

6. MLab (2019). MongoDB Hosting. Retrieved from https://mlab.com/.

7. Nakono (2019). Forecasts. Online Retail. Total Expenditure and Average Spending per User. Retrieved from https://fusion.nakono.com/data/online-retail-total-expenditure-and-average-spendingper-user.

8. Natorina, A. (2018). Online retailers' management system of marketing commodity policy. Economic Annals-XXI, 174(11-12), 69-72. DOI: https://doi.org/10.21003/ea.V174-11.

9. Nielsen (2018). Future Opportunities In FMCG E-Commerce. Report. Retrieved from https://www.nielsen.com/mena/en/insights/report/2018/future-opportunities-in-fmcg-ecommerce/\#.

10. Picodi (2018). Kakim byl onlayn-shopping v Ukraine v 2018 godu [What was online shopping in Ukraine in 2018]. Retrieved from https://www.picodi.com/ua/mozhna-deshevshe/kakim-byl-onlajnshopping-v-ukraine-v-2018-godu.

11. Reinartz, W. \& Imschlob, M. (2017). From Point of Sale to Point of Need: How Digital Technology Is Transforming Retailing. Marketing Intelligence Review, 9(1), 42-47. DOI: https://doi.org/10.1515/gfkmir-2017-0007.

12. Similarweb (2019). Website Traffic Statistics. Retrieved from https://www.similarweb.com/.

13. The Nielsen Company (2018). Insights. Retrieved from: https://www.nielsen.com/ua/uk/insights/

14. The State Statistics Service of Ukraine (2019). Catalogue of Official Statistical Publications. Retrieved from http://ukrstat.org/en.

15. The Ukrainian Retail Association (2019). Analytics. Retrieved from https://rau.ua/en/analyticsen/.

16. TNS, Kantar Group Company (2019). Brave mobile Ukraine. Retrieved from https://tns-ua.com/.

Manuscript received 18 August 2019

Симбиоз офлайн и диджитал-ритейла: украинский контекст

\section{АЛЁНА АЛЕКСАНДРОвНА НАТОРИНА}

\author{
* кандидат экономических наук, и.о. заведующего кафедры международной \\ экономики, учета и финансов ЧВУЗ «Международный научно-технический \\ университет имени академика Юрия Бугая», \\ пер. Магнитогорский, 3, г. Киев, 02000, Украина, \\ тел.:00-380-044-2915053, e-mail: alyonanatorina@gmail.com
}

Обосновано и научно доказано, что ритейл является одной из составляющих экономики Украины в контексте обеспечения ее устойчивого развития. Детерминировано симбиоз офлайн и диджитал-ритейла как один из альтернативных вариантов успешной деятельности в современной среде с перманентными рыночными изменениями, учитывая тренд диджитализации. Цели статьи 
Alona O. Natorina.

The Symbiosis of Offline and Digital Retail: Ukrainian Context

- исследование ландшафта и особенностей диджитал и офлайн-бизнеса ритейлеров, а также разработка рекомендаций относительно персистентного развития диджитал-бизнеса для ритейлеров с традиционной торговой сетью в контексте украинских реалий. Методическим инструментарием исследования являются общенаучные подходы - системный, структурный, комплексный, процессный; методы - научной дедукции и индукции, системного, логического и сравнительного анализа, синтеза, сравнения и аналогии. Исследованы крупнейшие украинские ритейлеры в сегменте food-ретейл, реализующие симультанно диджитал и офлайн-бизнес. Определены объемы онлайн-торговли в общей структуре товарооборота Украины. Проведен компаративный анализ объемов затрат онлайн-покупателей в Украине, Восточной Европе и мире. Обоснованы перспективы ведения диджитал-бизнеса. Диагностированы особенности деятельности онлайн-покупателей и определено их диджитал-активность. Проанализировано развитие диджитал-бизнеса food-ритейлеров и интерпретированы тренды украинского онлайн ритейла. Базируясь на результатах диагностики деятельности украинских ритейлеров в сегменте food-ритейл, и, учитывая текущие рыночные тенденции, определены перспективные направления персистентного прогрессивного развития диджитал-бизнеса. Апробация предоставленных в статье рекомендаций свидетельствует о целесообразности их применения ритейлерами для максимального удовлетворения гетерогенных запросов, потребностей и предпочтений онлайнпокупателей, а также стремительной экспансии новых рыночных сегментов.

Ключевые слова: диджитализация, диджитал-бизнес, диджитал-трансформация, офлайнбизнес, ритейл.

$$
\begin{gathered}
\text { Mechanism of Economic Regulation, 2019, No 3, 39-48 } \\
\text { ISSN 1726-8699 (print) }
\end{gathered}
$$

\section{Симбіоз офлайн та діджитал-ритейлу: український контекст}

\section{АльОНА ОЛЕКСАндРівНА НАТОРінА"}

* кандидат економічних наук, в.о. завідувача кафедри міжнародної економіки, обліку та фінансів ПВНЗ «Міжнародний науково-технічний університет імені академіка Юрія Бугая», провул. Магнітогорський, 3, м. Київ, 02000, Україна, тел.:00-380-044-2915053, e-mail: alyonanatorina@gmail.com

Обгрунтовано та науково доведено, що ритейл є однією зі складових економіки України у контексті забезпечення її сталого розвитку. Детерміновано симбіоз офлайн та діджитал-ритейлу як один з альтернативних варіантів успішної діяльності у сучасному середовищі з перманентними ринковими змінами, з огляду на тренд діджиталізації. Цілі статті - дослідження ландшафту й особливостей діджитал та офлайн-бізнесу ритейлерів, а також розробка рекомендацій щодо персистентного розвитку діджитал-бізнесу для ритейлерів з традиційною торговельною мережею у контексті українських реалій. Методичним інструментарієм дослідження є загальнонаукові підходи - системний, структурний, комплексний, процесний; методи - наукової дедукції й індукції, системного, логічного та компаративного аналізу, синтезу, порівняння й аналогії. Досліджено найбільші українські ритейлери у сегменті food-ретейл, що реалізують симультанно діджитал та офлайн-бізнес. Визначено обсяги онлайн-торгівлі у загальній структурі товарообігу України. Проведено компаративний аналіз обсягів витрат онлайн-покупців в Україні, Східній Європі та світі. Обгрунтовано перспективи ведення діджитал-бізнесу. Діагностовано особливості діяльності онлайн-покупців та визначено їх діджитал-активність. Проаналізовано розвиток діджитал-бізнесу food-ритейлерів та інтерпретовано тренди українського онлайн ритейлу. Базуючись на результатах діагностики діяльності українських ритейлерів у сегменті food-ритейл, та, враховуючи поточні ринкові тенденції, визначено перспективні напрями персистентного прогресивного розвитку діджитал-бізнесу. Апробація наданих у статті рекомендацій засвідчує доцільність їх застосування ритейлерами для максимального задоволення гетерогенних запитів, 


\section{А. О. Наторіна.}

потреб і уподобань онлайн-покупців, а також стрімкої експансії нових ринкових сегментів.

Ключові слова: діджиталізація, діджитал-бізнес, діджитал-трансформація, офлайн-бізнес, ритейл.

JEL Codes: L81, M1

Tables: 2; Figures: 3; References: 16

Language of the article: English

Лimepamypa

1. Cable (2019). Worldwide broadband speed league 2019 [Electronic resource]. - Accessed mode : https://www.cable.co.uk/broadband/speed/worldwide-speed-league/.

2. EVO Company (2019) [Electronic resource]. EVO. Business Publication. - Accessed mode : https://evo.company/ua/.

3. Grewal, D. The Evolution and Future of Retailing and Retailing Education / D. Grewal, S. Motyka, M. Levy // Journal of Marketing Education. - 2018. - Vol.40(1). - P. 85-93. DOI: https://doi.org/10.1177\%2F0273475318755838.

4. Hagberg, J. The digitalization of retailing: an exploratory framework / J. Hagberg, M. Sundstrom, N. Egels-Zanden // International Journal of Retail \& Distribution Management. - 2016. - Vol. 44 (7) - P. 694-712. DOI: https://doi.org/10.1108/IJRDM-09-2015-0140.

5. Icon, C. Challenges for digital transformation - towards a conceptual decision support guide for managers / C. Icon, D. Power // Journal of Decision Systems. - 2018. - Vol. 27. - P. 38-45. DOI: https://doi.org/10.1080/12460125.2018.1468697.

6. MLab [Electronic resource]. MongoDB Hosting. - 2019. - Accessed mode : https://mlab.com/.

7. Nakono. Forecasts [Electronic resource]. Online Retail. Total Expenditure and Average Spending per User. - 2019. - Accessed mode : https://fusion.nakono.com/data/online-retail-total-expenditure-andaverage-spending-per-user.

8. Natorina, A. Online retailers' management system of marketing commodity policy / A. Natorina // Economic Annals-XXI. - 2018. - Vol. 174 (11-12). - P. 69-72. DOI: https://doi.org/10.21003/ea.V174-11.

9. Nielsen. Future Opportunities In FMCG E-Commerce [Electronic resource]. Report. - 2018. Accessed mode: https://www.nielsen.com/mena/en/insights/report/2018/future-opportunities-infmcg-ecommerce/\#.

10. Picodi. Каким был онлайн-шоппинг в Украине в 2018 году. - Режим доступу: https://www.picodi.com/ua/mozhna-deshevshe/kakim-byl-onlajn-shopping-v-ukraine-v-2018-godu.

11. Reinartz, $W$. From Point of Sale to Point of Need: How Digital Technology Is Transforming Retailing / W. Reinartz, M. Imschlob // Marketing Intelligence Review. - 2017. - Vol. 9(1). - P. 4247. DOI: https://doi.org/10.1515/gfkmir-2017-0007.

12. Similarweb [Electronic resource]. Website Traffic Statistics. - 2019. - Accessed mode : https://www.similarweb.com/.

13. The Nielsen Company [Electronic resource]. Insights. - 2018. - Accessed mode : https://www.nielsen.com/ua/uk/insights/.

14. Державна служба статистики України [Електронний ресурс]. Каталог офіційних статистичних публікацій у 2019 році. - Режим доступу : http://ukrstat.org/en.

15. Асоціація ритейлерів України. Аналітика. - 2019. - Режим доступу: https://rau.ua/en/analyticsen/.

16. TNS, Kantar Group Company. Brave mobile Ukraine [Електронний ресурс]. Презентація доповіді А. Шахдінарян, керівника Інтернет-досліджень Kantar TNS. - 2019. - Режим доступу : https://tns-ua.com/. 